\title{
Peculiarities of Digitalization of the Agro-industrial Complex of Belgorod Region as a Spatial Socio- Economic System
}

\author{
Anna Kogteva \\ Department of Applied economicss and Economic Security \\ Belgorod State National Research University \\ Belgorod, Russia \\ kogteva@bsu.edu.ru \\ Anna Kulik \\ Department of Applied economicss and Economic Security \\ Belgorod State National Research University \\ Belgorod, Russia \\ kulik@bsu.edu.ru
}

\author{
Natalya Gerasimova \\ Department of Applied economicss and Economic Security \\ Belgorod State National Research University \\ Belgorod, Russia \\ ngerasimova@bsu.edu.ru \\ Natalya Shevtsova \\ Voronezh State Agrarian University named after Emperor Peter \\ the Great \\ Voronezh, Russia \\ shevtsova/_nm@mail.ru
}

\begin{abstract}
The agro-industrial complex (AIC) is an important intersectoral complex of regions, as spatial socioeconomic systems, and the country as a whole, the main purpose of which is to provide food to the population in the established conditions of import substitution. The current situation has given an impetus to the growth of agricultural production, which is impossible without the use of modern equipment and technologies in order to increase production efficiency, as well as resource conservation. Digitalization technologies are one of the main vectors of development of the agro-industrial complex. According to the analysis, it was revealed that projects on both digitalization of crop production and digitalization of animal husbandry are being implemented in the Belgorod region. Summing up the study, we can conclude that the introduction of digital technologies in agriculture of the region contributes to the systematization of information to improve the accuracy of land, volumes of crops, livestock productivity, and increase the level of control of production within the framework of the effective use of technology and the level of efficiency of staff. In higher educational institutions, technology parks and innovation centers; cooperation with meteorological organizations and preparation of geoinformation maps to prevent force majeure situations.
\end{abstract}

Keywords-agribusiness, digitalization, drone, crop production, livestock, Internet of things, SELEX.

\section{INTRODUCTION}

The crisis of 2014 had a certain impact on the country's economy - a decrease in exports due to the termination of trade relations, as well as sanctions pressure from the West, and a drop in imports. The development of the agro-industrial complex is important in the economy of the regions and the country at the present time. Due to the current situation, the regions are faced with the need to find and use reserves for the growth and development of agricultural production, improving the quality of life of the rural population. At this stage, the mainstream of the sectoral state policy with regard to agricultural production is its growth based on the active implementation of digital technologies [2].

According to research, the introduction of information systems makes it possible to reduce production costs by 6-10 $\%$, and the cost of circulation by $7-20 \%$. Thus, at the enterprise level, the effectiveness of the use of information systems reduces inventories by 3-4 times, and working capital by $7-10 \%$ [3].

As part of the digitalization of the sectors of agriculture, the Ministry of Agriculture of the Russian Federation has completed the development of the departmental project «Digital Agriculture» with the implementation period defined in the range - 2019-2024. The goal of the project: digital transformation of agriculture through the introduction of digital technologies and platform solutions to ensure a technological breakthrough in the agricultural sector and increase labor productivity in «digital» agricultural enterprises by 2 times by 2024. [5]

\section{METHODS}

General scientific methods of analysis and synthesis were used as research tools, as well as specific research methods such as: monographic method, abstract-logical, calculationgraphic, economic-statistical, comparative financialeconomic analysis, etc.

\section{MAIN PART}

The introduction of digital technologies in the agricultural sector will:

- increase labor productivity in the agricultural industry;

- increase the prestige of agricultural activities;

- reduce the risk of «human factor» in production;

- reduce the costs of circulation and production.

The work involves the study of the digitalization of the agroindustrial complex on the example of the Belgorod region. 
The main objectives of the study include:

- the study of the main points of development of the agroindustrial complex in the territory of the Belgorod region;

- the need for digital transformation of agricultural activities;

- the level of digitalization of the agroindustrial complex of the Belgorod region.

TABLE I. DYNAMICS OF EXPORTS AND IMPORTS OF THE

BELGOROD REGION

\begin{tabular}{|l|c|c|c|c|c|}
\hline Indicator & 2014 & 2015 & 2016 & 2017 & 2018 \\
\hline $\begin{array}{l}\text { Imports, mln. } \\
\text { USD }\end{array}$ & 3268,2 & 1822,7 & 1402,4 & 1610,5 & 1486,5 \\
\hline $\begin{array}{l}\text { Exports, mln. } \\
\text { U.S. }\end{array}$ & 3176,0 & 2426,1 & 2190,5 & 2789,8 & 3339,5 \\
\hline $\begin{array}{l}\text { Trade balance, } \\
\text { mln. USD }\end{array}$ & $-92,2$ & $+603,5$ & $+788,1$ & $+1179,4$ & +1853 \\
\hline $\begin{array}{l}\text { Coefficient of } \\
\text { coverage of } \\
\text { imports by } \\
\text { exports, \% }\end{array}$ & 97,2 & 133,1 & 156,2 & 173,2 & 224,7 \\
\hline \multicolumn{2}{|l|}{ Source: [10] }
\end{tabular}

In accordance with the highlighted objectives of the research, the analysis of data from the Territorial body of the Federal State Statistics Service in the Belgorod region, materials of agricultural exhibitions and forums, as well as articles of periodicals and educational literature was carried out.

When writing the work, methods of analysis, statistical data grouping and synthesis were used.

Among the economically developed subjects of the Russian Federation, the Belgorod Oblast occupies a leading position due to its powerful agro-industrial complex, covering all areas of development - crop production, pig breeding, poultry farming, dairy and meat cattle breeding[6].

It is advisable to note that the effective development of the agro-industrial complex on the territory of the Belgorod region is based on a number of socio-economic and natural prerequisites, which primarily include:

- economic and geographical position;

- favourable climate for the development of agriculture;

- sufficient water resources;

- fertile black earth soils;

- availability of the necessary labor potential for the development of agro-industrial complex industries [6].

The program of digitalization of agriculture is of great importance for the Belgorod Oblast, because the agricultural sector accounts for up to $20 \%$ of the gross product of the region. The increased attention to the agricultural sector is determined by the need to meet social and production indicators, which are prescribed in the strategic development program: the Belgorod region has a high percentage (32.6\%) of the rural population.
The Belgorod region is one of the pilot territories for the implementation of digitalization in agriculture - the region's exports are twice as large as its imports (Table 1).

According to the table, the volume of imports in the region decreased significantly between 2014 and 2018 - by $54.5 \%$ in 2018 compared to 2014

At the same time, the volume of exports, which declined in 2015 due to the unstable situation in Ukraine and the imposition of

Western sanctions, showed growth - by $37.6 \%$ in 2018 compared to 2015 , while exceeding the level of 2014 by $5.1 \%$. This dynamics is associated with the growth of domestic exports, as well as the development of import substitution policy in the country. A positive development is the excess of the share of exports over imports since 2015, as evidenced by the trade balance (for 2018 the figure was + $\$ 1,853$ million), as well as the increase in the import coverage ratio by $91.6 \%$ in 2018 compared to 2015 .

Initially, the development of digital technologies in the Belgorod Oblast agro-industrial complex was limited to the use of personal computers, software, technologies for creating and maintaining various information resources on the Internet (sites), nowadays digitalization has touched the technological processes of production and control over the efficiency of their organization.

Crop production is an important agricultural industry in the Belgorod region. Barley, wheat, corn, sugar beets, sunflowers, and indoor and outdoor vegetables are grown in the region (Table 2 ).

In 2014-2018, crop production in Belgorod Region increased the yield of outdoor and indoor vegetables (by $26.4 \%$ ) and sunflowers (by 36\%); this trend is also associated with the implementation of import substitution policy within the region, when it is required to increase the production of this group, which is subsequently used for the production of import-substituting products.

TABLE II. GROSS HARVEST OF CROPS IN BELGOROD REGION,

\begin{tabular}{|l|c|c|c|c|c|}
\hline \multicolumn{1}{|c|}{ Indicator } & 2014 & 2015 & 2016 & 2017 & 2018 \\
\hline $\begin{array}{l}\text { Cereals and } \\
\text { legumes }\end{array}$ & 35248 & 31297 & 35035 & 35849 & $\begin{array}{c}33 \\
858\end{array}$ \\
\hline Corn & 9276 & 9977 & 11773 & 7681 & 8380 \\
\hline Sugar beet & 28081 & 27311 & 41045 & 30042 & $\begin{array}{c}26 \\
712\end{array}$ \\
\hline Sunflower seeds & 2969 & 3222 & 3752 & 2972 & 4037 \\
\hline Potatoes & 4843 & 5071 & 4382 & 4354 & 4432 \\
\hline $\begin{array}{l}\text { Vegetables in } \\
\text { open and closed } \\
\text { ground }\end{array}$ & 2054 & 2239 & 2501 & 2438 & 2596 \\
\hline $\begin{array}{l}\text { Source: [10] } \\
\text { Sourn }\end{array}$ & & & & &
\end{tabular}

In 2017. Belgorod region became an experimental zone of the program «National Technological Initiative» in the field of agriculture - within the region were carried out work on the use of drones for land inventory, tracking crops and the quality of work in the fields, etc.

The project, supported by the regional government, the Aeronet Association and the Foundation for Assistance to Innovations, was called «AgroNTI for Business». The 
experimental site was 20,000 hectares of land of a large agricultural holding. In 2018, 100 thousand hectares of land were allocated for this project.

During the experiment, accurate four-layer digital maps of the fields with the mapping of roads, slopes with a degree of steepness, spring watercourses, with the alignment of field boundaries with cadastral plots, electronic field passports were created. Agronomists could see in real time the growth of biomass, weed outbreaks, pest infestations, field readiness for sowing and harvesting. Weather forecast made it possible to plan work on plant protection and fodder harvesting. Also a plus of drones is their ability to reach places inaccessible to ground vehicles, effectively treat crops and forest belts against pests. There are also disadvantages: a quadcopter cannot lift a large volume of payload into the sky, its battery life is limited, and the use of a drone is expensive. The economists calculated that if the agricultural holding decides to extend this experience to all of its 60 thousand hectares, they would have to invest 125 million rubles, or 2,000 rubles per hectare. - or more than 2,000 rubles per hectare. At the same time, making decisions based on drone data converted into digital maps gave 1.5 thousand rubles extra profit per hectare of sunflower. Consequently, the investment pays off in less than two seasons [8].

In 2018, the results for some indicators exceeded the achievements of 2017 dozens of times. The economic effect in the area of land fund audit increased by more than 22 times - the planned indicators exceeded 50 million rubles. Optimization of transportation costs increased 4.5 times. Maps of arable cadastral borders on the territory of 51 thousand hectares were compiled and compared. It turned out that 6.5 thousand hectares are registered in the cadastre, but in fact is not used for agricultural production. Thanks to this data we managed to optimize tax and rental payments amounting to $25 \mathrm{mln}$ rubles. The dynamics of cost reduction per hectare of arable land in 2017 was 1,388 rubles per hectare, in 2018. - More than 2500 rubles, in 2019, according to experts' estimates, costs will be reduced already by 3800 rubles per hectare.

The experiment with drones has become interesting for other regions - in 2018 a new experimental site was opened in Primorye, the resident companies are negotiating with Krasnodar Territory, Leningrad Region, Krasnoyarsk.

Taking into account the fact that in the territory of Belgorod region $100 \%$ of the land is in circulation, and this with a difficult terrain, it is necessary to pay special attention to the condition of the soil. Together with the Center for Agrochemical Service in the region in 2015-2016, the digitization of fields to create a geographic information system was started. Currently, all the fields in the region are in the database: they are systematized by crops, producers, agrochemical condition of soils, if necessary, you can get all the necessary information and analytics.

The creation of the electronic map of agricultural land in the Belgorod region formed the basis for the creation of an information base of horticulture in Russia.

Among the new directions, of course, is the Internet of Things. Examples of solutions based on the Internet of Things are: controlling harvested crops from the bunker to the elevator, monitoring product quality and storage conditions, tracing the origin of food products, «smart» resource-saving farms and greenhouses. All of these solutions provide significant savings in material and technical resources and energy costs, and ensure the transparency of business processes and the safety of the resulting products.

One of the first effective solutions in this field is the RusAgro sugar beet storage control system. The system allows to control the state of piles (embankments) in which sugar beet is stored before being processed at the mill. Due to the length of the pits (hundreds of meters) and their vast location the control of temperature and humidity conditions was practically an impossible task before. Now, thanks to the use of autonomous IoT devices equipped with GPS-trackers, accelerometers, temperature and humidity sensors, it is possible to know about the state of the kagat in a particular point, in connection with GIS. Several tens of thousands of autonomous (up to five years of operation) installed devices are combined in the LoRaWAN network, which provides coverage of the entire storage area. This made it possible to reduce the loss of raw materials by $20 \%$ [9].

Digital technologies also touched the equipment of agricultural machinery - the system «Navigator-Agro» contributes to the automation of machine parks of agricultural enterprises, the installation of fuel sensors and GPS - devices that transmit signals to the cloud Internet service allows you to analyze the effectiveness of the use of equipment from anywhere in the world. These devices allow tracking of drivers' work and rest schedule, as well as the location of machinery, the amount of work and fuel consumption.

TABLE III. KEY INDICATORS OF THE DAIRY INDUSTRY IN BELGOROD REGION

\begin{tabular}{|l|c|c|c|c|c|}
\hline \multicolumn{1}{|c|}{ Indicator } & 2014 & 2015 & 2016 & 2017 & 2018 \\
\hline $\begin{array}{l}\text { Milk production, } \\
\text { thousand tons }\end{array}$ & 544,2 & 531,5 & 542,6 & 593,6 & 623,8 \\
\hline $\begin{array}{l}\text { Milk yield per cow, } \\
\mathrm{kg} .\end{array}$ & 5839 & 5915 & 6163 & 6714 & 6934 \\
\hline
\end{tabular}

Source: [10]

Oblast, but the enterprises operating there show very good results (Table 3 ).

As shown in Table 3, milk production for 2014-2018 increased markedly - by $14.6 \%$ in 2018 compared to 2014 . In addition, milk yield per cow increased - by $1,095 \mathrm{~kg}$. (18.8\%) in 2018. The milk productivity of cows in the region is 6934 $\mathrm{kg}$ (the Russian average is $4134 \mathrm{~kg}$ ).

Enterprises of the dairy industry in the Belgorod region show high results: ZAO MK Avida ranks fourth in Russia in terms of production volume with an indicator of 70.5 thousand tons of raw milk. Also among the leaders are OOO GC «Green Valley» (13th place and 23.2 thousand tons of milk) and the collective farm named after Frunze (15th place and 20 thousand tons of milk). LLC Graivoronskaya Dairy Company ranks 29th with 13 thousand tons of milk, and CJSC Oskol Milk is 35th with 12.5 thousand tons of milk. The region's largest milk producers include FSNU Belgorod Research Institute of Dairy Farming of Rosselkhozacademy, CJSC Plemzavod Razumensky, Kolkhoz Sovetskaya Rossiya and CJSC Skorodnyanskoe, which also has a large Parmalat dairy product plant. There are also ZAO Tommoloko, ZAO Alekseevsky Dairy Canning Plant, OOO Rovenky- 
Masloryzavod, OAO Moloko, OOO Tulchinka.ru, OAO Shebekinsky Maslodelny Zavod in processing [4].

One of the directions of digitalization of the dairy industry is the use of the SELEX program in dairy cattle breeding, which accumulates all the basic information on animals in the database: origin, genotype, development, exterior appearance, complex evaluation, productivity in all lactations, udder evaluation, events (calving, insemination, start-ups).

The main functions of the program are:

- operative processing of primary data of zootechnical and pedigree accounting;

- operative management of production;

- operational management of breeding and pedigree work;

- assigning classes (appraisal) to animals and its analysis;

- livestock production forecasting;

- filing cabinets;

- work with young animals;

- herd turnover;

- economic and statistical analysis.

The use of SELEX software at the dairy enterprises allows the creation of a closed cycle of information processing on cattle, thereby coordinating the activities of specialists and increasing the efficiency of enterprises.

Since 2012, the Belgorod region is considered a leader in Russia in poultry and pork production. The main indicators of meat production are shown in Table 4.

TABLE IV. MAIN INDICATORS OF THE MEAT INDUSTRY IN THE

\begin{tabular}{|l|c|c|c|c|c|}
\hline \multicolumn{1}{|c|}{ Indicator } & 2014 & 2015 & 2016 & 2017 & 2018 \\
\hline $\begin{array}{l}\text { Cattle and } \\
\text { poultry for } \\
\text { slaughter } \\
\text { (live } \\
\text { weight), } \\
\text { thousand } \\
\text { tons }\end{array}$ & 1531,4 & 1618,7 & 1634,3 & 1705 & 1705,5 \\
\hline cattle & 36,5 & 35,6 & 37,2 & 35,9 & 35,6 \\
\hline pigs & 722,1 & 749,4 & 787,4 & 816,6 & 860,7 \\
\hline $\begin{array}{l}\text { sheep and } \\
\text { goats }\end{array}$ & 2,3 & 2,5 & 1,9 & 2 & 2,1 \\
\hline bird Poultry production & $\begin{array}{c}830,5 \\
\text { for 2014-2018 increased }\end{array}$ & $\begin{array}{c}807 \\
\text { parkedly }\end{array}$ \\
\hline
\end{tabular}

by $4.7 \%$ in 2018 , which is a positive development. There is a noticeable decrease in beef production - by $2.5 \%$, which is a consequence of redistribution of investments in promising sectors of the region - poultry and pork. This trend is confirmed by data on the volume of pork produced in the region - in 2018 the figure was 860.7 thousand tons, an increase of $19.2 \%$ from 2014
Automation has also touched pig breeding - the accounting of livestock, reproductive and breeding indicators at the enterprises of the region is now carried out with the help of $1 \mathrm{C}$ «Breeding in livestock breeding. Pig breeding».

The program allows:

- create a unified database of animals with their pedigree

- Automate the production accounting (group and individual animals accounting);

- Automate the registration of veterinary drugs and feed;

- monitor the movement of animals in terms of groups and farms, the causes of culling and mortality;

- analyze the work of individual employees and the farm as a whole;

- accelerate the process of breeding and testing of breeds and lines for combinational ability in hybridization;

- promote achievement of high parameters of animal productivity.

As a result of the program implementation, it is planned to reduce feed costs, the cost of pork, improve product quality, increase productivity, etc

One of the areas of digitalization in both the dairy and meat industries is the chipping of animals. This system has been in operation in Belgorod Region for more than 10 years. In 2014, the region began identifying cattle and small ruminants kept by household farms, collective farms and individual entrepreneurs. By 2018, $80 \%$ of cattle and $34 \%$ of small cattle in these farms received tags. The work on the full identification of animals currently continues.

The chipping procedure is a painless injection for the animal. The microchip, a chip with a unique digital code, is encased in a biocompatible glass that excludes rejection, in an individual syringe.

After injection, the chip grows connective tissue for a week and cannot move under the skin. The chips are read by special scanners. After each animal is chipped, an international registration certificate is issued, which includes name (nickname), identification number, age, state of health and purpose of use. The certificate is filled out in Russian and English.

Registering the animals born in or imported into the Belgorod Region includes assigning a unique number, tagging, and making a note in the animal passport or issuing a document on it. The numbers are entered into an electronic database. When its formation is completed, the information will be combined with the data on the animals in the agricultural enterprises, resulting in a unified regional database. Also, the data of the identified livestock are regularly entered in the tracing (moving) program, which allows you to track any movement of the animals put on record from birth to delivery to the meat processing plant [1].

In addition to digital technologies in the agricultural sector, affecting the production process and control over the 
work of organizations, the digitalization of the agricultural sector in the Belgorod region involves the implementation of the «Market Foodnet» project. This project is based on the digitalization of agriculture and the creation of digital solutions to unite agricultural producers through the digital space in the network to organize joint work and exchange of experience. For example, the problem of sales channels is acute: large holdings have them, smaller players do not have enough of them, there are problems with logistics. Small agricultural entrepreneurs cannot enter the networks because of the lack of production volume. «Market Foodnet» will allow to overcome these problems.

The development of digitalization of the Belgorod region's agro-industrial complex makes it possible to effectively organize the region's enterprises, while facing a number of difficulties, such as:

- the need for large amounts of funding;

- lack of personnel with the proper level of education, reorientation of higher education institutions in the new hightech environment;

- lack of demand due to the lack of awareness of agricultural producers in the region;

- unformed legal and regulatory framework in the field of digitalization of the agro-industrial complex;

- disproportionate development of the agroindustrial complex on the territory of the country;

- the impact of weather conditions on production, etc.

The solution to the problem of finance is to finance the implementation of digital technologies through state subsidies, as well as to attract additional investments in the region through the interest of potential investors.

The development of digitalization of agriculture in the Belgorod region implies the availability of qualified personnel to organize effective activities. At present, the personnel issue for the needs of agriculture is addressed by the Belgorod State National Research University, the Belgorod Agricultural Academy, the Belgorod State Agrarian University named after Gorky. V.Ya. Gorin and many other educational institutions, in addition, the regional innovation structure is represented by the following groups:

\section{Technoparks:}

- technopark in Belgorod;

- technopark at Belgorod State Technical University named after V.G. Shukhov;

- the «High Technologies» Technopark of the National Research University «Belgorod State University»;

- UNIC «Agro-technopark» of the Federal State Budgetary Educational Institution of Higher Professional Education Belgorod State Agrarian University.

\section{2. business incubators:}

- Innovation business incubator of the OGBU «BRRIC»;
- the business incubator of the «High Technologies» Technopark of Belgorod State University;

- Innovation Business Incubator of V.G. Shukhov BSTU;

- business incubator UNIC «Agro-Technopark» of the Federal State Budgetary Educational Institution of Higher Professional Education Belgorod State Agrarian University.

Engineering centers:

- engineering center of land transport BSTU named after V.G. Shukhov;

- the engineering center of Belgorod State University;

- Regional Engineering Centre of Regional State Budgetary Institution «BRRIC»;

4. Innovation and technology transfer centers:

- the center of high technologies of BSTU named after V.G. Shukhov;

- BRRIC» cluster development center;

- the center of information and consulting activity and project management of Belgorod State Agrarian University, etc., etc. [7].

Thus, the difficulties of digitalization of the agroindustrial complex are solvable, even at the regional level, with due attention to the problem on the part of the regional administration and local authorities of the regions.

\section{CONCLUSION}

According to the study, it was found that digital technology is an important component of the development of the agroindustrial complex of Russia in the current conditions of development

The Belgorod region was chosen to analyze the implementation of digital technologies in the agro-industrial complex, a region with a highly developed agro-industrial and scientific-educational complex with achievements in crop and livestock production.

Digital technologies have been implemented in the region's agro-industrial complex for more than 10 years and have already brought a significant effect of implementation at the enterprises of the Belgorod region.

At present, the region is a pilot site for the introduction of drones for land inventory, crops and quality of work in the fields, and the creation of an electronic map of agricultural land in the Belgorod region has formed the basis for creating an information base for horticulture in Russia. Fuel level sensors, as well as GLONASS and GPS navigation systems, have been installed on the region's agricultural machinery.

Digital technologies are also being introduced in the cattle breeding sector of Belgorod Region's agroindustrial complexes - dairy production is being automated using SELEX software, and 1C software «Breeding in cattle breeding» is being introduced at pig breeding complexes. Pig breeding» to systematize large amounts of information and track production processes. 
Digitalization of the Belgorod region agroindustrial complex contributes to:

- reduction of production costs;

- reduction of inventories and current assets;

- optimization of tax and lease payments;

- improved product quality;

- production automation;

- creation of unified information bases to reduce the time required to process large amounts of information, etc.

Despite all the advantages of digitalization of the agroindustrial complex in the region, this process is associated with a number of problems - economic and organizational. The solution of these problems is associated with the implementation of effective measures of local government and public authorities in the framework of increasing the investment attractiveness of the industry and the region as a whole, supporting scientific and educational activities, subsidizing, as well as in the legislative and informational aspects.

\section{ACKNOWLEDGMENT}

The study was carried out within the framework of an intra-university grant of the National Research University «BelSU» in accordance with Order No. 826-OD of 14.08.2020, the theme of the project «Smart specialization in the agro-industrial complex of the region: digital transformation and convergent technologies».

\section{REFERENCES}

[1] A. Belaya, Recognize and take into account: why an animal identification system is needed, Agroinvestor, 2016. URL: Access mode:https://www.agroinvestor.ru/technologies/article/23594-

raspoznat-i-uchest-dlya-chego-neobk hodima-sistema-identifikatsiiselkhozzhivotnykh/ (accessed 12.10.2019).

[2] A.A. Belostotsky, "Strategic guidelines for digitalization of the economy in the agroindustrial complex: sustainability, efficiency, innovation”, Economics and Entrepreneurship, 2017, № 12-1 (89-1), pp. 908-911.

[3] Sh. Zhantemirov, "Information in the modernization of agriculture", Transport business in Russia, 2015, № 1, pp. 97-99.

[4] V. G. Zakshevskiy, "Directions of the regional agroindustrial complex development on the basis of innovation", Economics, labor, management in agriculture, 2012, №1, pp. 25-28.

[5] V. F. Fedorenko, N. P. Mishurov, O.V. Kondratieva, Golden Autumn - the main agrarian forum of Russia, Collection of materials of the 20th Russian agroindustrial exhibition "Golden Autumn-2018”, Moscow, 2018, 300 p.

[6] A. N. Kogteva, N. A. Gerasimova, Agroindustrial complex as a factor in economic security of the region, Economic security of socioeconomic systems: challenges and opportunities: collection of scientific papers of the international scientific-practical conference, Belgorod, 2018, pp. 143-148

[7] On amending the resolution of the Government of the Belgorod region, 2010. URL: https://base.garant.ru/42731598/ (accessed 12.10.2019).

[8] Drone lifted. Regions are urged to more actively implement digital technologies in agriculture, Rossiyskaya Gazeta - Ekonomika Tsentralnogo Okrug, 2018. URL: https://rg.ru/2018/09/18/regcfo/selskoe-hoziajstvo-perejdet-na-cifru.html (accessed 10.11.2020).

[9] O. Privalov "Space heights of the agroindustrial complex. Technologies and agriculture", Kommersant:Economic forum,

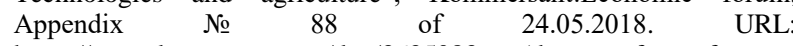
https://www.kommersant.ru/doc/3635083 (date of reference: 12.10.2019). (accessed 10.11.2020)

[10] Territorial body of the Federal State Statistics Service in the Belgorod region. URL: https://belg.gks.ru (date of access: 10.10.2019).
[11] R. Berger, The digital transformation of industry, BDI, 2015, $257 \mathrm{p}$.

[12] D. Tapscott, The Digital Economy: Promise and Peril in the Age of Networked intelligence, Paperback, 1994, 368 p. 